\title{
Immediate Effect of Clam Harvesting on Intertidal Benthic Communities in the Mudflat Zones of Kneiss Islands (Central Mediterranean Sea)
}

\author{
Nawfel Mosbahi' ${ }^{1}$ Jean-Philippe Pezy², Jean-Claude Dauvin ${ }^{2 *}$ and Lassad Neifar ${ }^{1}$
}

${ }^{1}$ Laboratoire de Biodiversité et Ecosystèmes Aquatiques, Faculté des Sciences de Sfax, Université de Sfax, BP, Sfax, Tunisie

${ }^{2}$ Normandie Univ, Unicaen, Unirouen, UMR M2C, Caen, France

\begin{abstract}
The Gulf of Gabès in southern Tunisia shows the highest tidal ranges of the Mediterranean Sea. During spring tides, the very large intertidal sand and mudflat zone is exploited for clam harvesting, mainly targeted on the species Ruditapes spp. mainly Ruditapes decussatus by Linnaeus in 1758 . To assess the short-term impact of clam harvesting on the intertidal macrobenthos of the Kneiss Islands mudflats, a control-impact study was set up in September and December 2013 using a BACl (Before-After-Control-Impact) design, with a control station and eight stations fished for clams. Significant decreases in total macrofauna, benthic polychaetes (mainly Nephtyidae, Eunicidae, Spionidae, Maldanidae, Sabellidae and Cirratulidae) and $R$. decussatus were observed from before to after the harvesting initiated. In the future, it would be very important to control this human activity, due to its negative impact on the surrounding macrofauna, which represent essential prey for fishes and birds living in this protected area.
\end{abstract}

Keywords: Gulf of Gabès; Clam harvesting; Benthic macrofaunal; Ruditapes decussatus

\section{Introduction}

The intertidal zone is an important source of natural resources that are harvested by professional and recreational fishers mainly for financial gain. Harvesting involves turning over sediment to capture target species such as molluscs, crustaceans and polychaetes. This may have a negative impact on the associated benthic infauna community, such as observed in the Lowes Cove communities from Walpole, Maine (USA) [1]. This disturbance could have a variety of effects depending on the benthic community, the surface-area disturbed and fishing pressure; all these factors vary between different fisheries and according the digging areas and fishing gear [2-4]. Nevertheless, many studies show that, in the intertidal zone, manual or mechanical harvesting of target intertidal bivalves may cause strong disturbances and negative effects on the benthic infauna communities, i.e. significant decrease in the number of taxa or/and abundance of the macrofauna due to fishing activities [5-9]. Conversely, Sousa Leitao and Gaspar [10] reported that the effect of using two types of gear (harvesting knife and hand dredge) has very slight and similar immediate impacts on the harvesting of Cerastoderma edule by Linnaeus. However, studies by Carvalho et al. [8]. in same area (Lagos, South Portugal), but on the subtidal zone, reveal an immediate negative impact on the macrofauna as a result of fishing of the razor clam Ensis siliqua by Linnaeus. Moreover, in a study of the impact of rake harvesting on the intertidal zone of the western Cotentin (western part of the English Channel, France), Beck et al. [11] show that the effect of harvesting depends on the sediment type and hydrodynamic regime.

The Gulf of Gabès (Tunisia) is a semi-enclosed sea showing amongst the highest tidal ranges in the Mediterranean, comparable to those observed in the northern part of the Adriatic. Tides are semidiurnal and display a distinct spatial pattern with ranges of up to $2.3 \mathrm{~m}$ at spring low tides which allow access at low tide to the intertidal zone [12]. The clam harvesting sector in the Gulf of Gabès has attracted the interest of the Tunisian government due to the social significance of this activity for the local population. Clam harvesting is carried out mainly by women, and the fishery represents an important contribution to the economy by providing of an exportable product. Clam stocks on the foreshore of southern Tunisia have been estimated at more 4,500 tonnes [13].

Additionally, clam harvesting is a traditional activity, using sickles to harvest the target species Ruditapes decussatus (Linnaeus, 1758). However, with the aim to preserve the stock during the summer reproductive period, the fishing activity is seasonal and extends from the 1st October of one year to the 15th May of the following year. In the central part in the Gulf of Gabès, around the Kneiss Islands, nearby 400 fishers on foot pursue this activity every day during the harvest period. The Kneiss Islands foreshore is characterized by a succession of areas with sand and muddy sand bottom [14] with a rich macrobenthic community [15]; hence, this fishing activity could lead to human trampling that combined with clam fishing would have an impact on the infauna.

The sickles used by the fisherwomen are about $20 \mathrm{~cm}$ long and $1.5 \mathrm{~cm}$ in width (Picture 1). The number of fishers working in the intertidal zone of the Kneiss Islands ( $480 \mathrm{ha}$ ) is about 400 (personal observation). Normally, the minimum authorized size for Ruditapes decussatus is $>35 \mathrm{~mm}$, but smaller clams are regularly harvested during the period from 1 October- $15^{\text {th }}$ May with about 20 days of harvest per month over a total of 150 days. Fisherwomen can harvest about $4 \mathrm{~kg} /$ day/fisher, and they sell their harvest just after fishing to a wholesaler who markets the clams mainly for export, as the local consumption is insignificant (Figure 1). Therefore, we estimate that about 240 tonnes could be collected per year in the target zones of the Kneiss Islands.

*Corresponding author: Jean-Claude Dauvin, Normandie Univ, Unicaen Unirouen, UMR M2C, CNRS 6143, 24 rue des Tilleuls, 14000 Caen, France, Tel: +33(0)23156572; E-mail: jean-claude.dauvin@unicaen.fr

Received July 22, 2016; Accepted November 08, 2016; Published November 10, 2016

Citation: Mosbahi N, Pezy JP, Dauvin JC, Neifar L (2016) Immediate Effect of Clam Harvesting on Intertidal Benthic Communities in the Mudflat Zones of Kneiss Islands (Central Mediterranean Sea). J Aquac Res Development 7: 454. doi: 10.4172/2155-9546.1000454

Copyright: (c) 2016 Mosbahi N, et al. This is an open-access article distributed under the terms of the Creative Commons Attribution License, which permits unrestricted use, distribution, and reproduction in any medium, provided the original author and source are credited. 
Citation: Mosbahi N, Pezy JP, Dauvin JC, Neifar L (2016) Immediate Effect of Clam Harvesting on Intertidal Benthic Communities in the Mudflat Zones of Kneiss Islands (Central Mediterranean Sea). J Aquac Res Development 7: 454. doi: 10.4172/2155-9546.1000454

Page 2 of 7

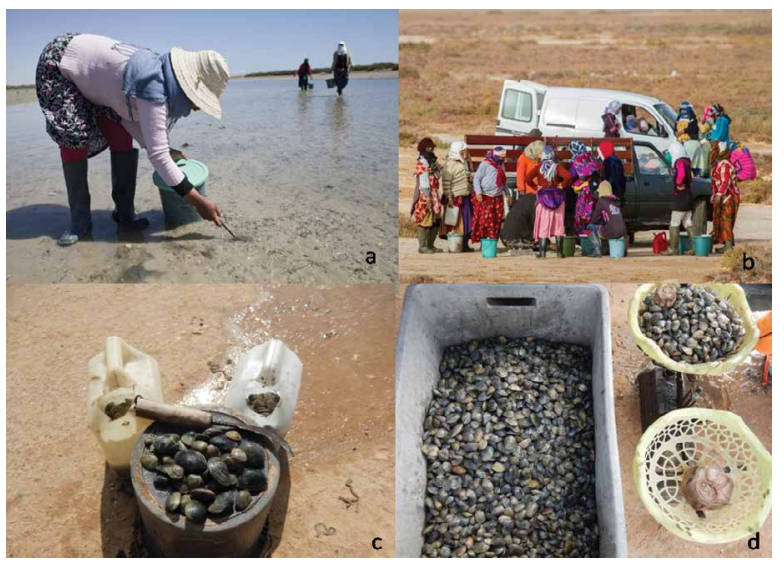

Picture 1: Clam harvesting activity in the Kneiss Islands: (a) Clam harvesting by sickle, (b) Women harvesters, (d) Clam collection gear, (d) Sale of clams.

This assessment is of a same order of magnitude as the estimate given by Nouaili [13] for the Kneiss intertidal zone: $210 \mathrm{t}$.

The aim of this study is to estimate, for the first time, the effects of clam harvesting on the macrobenthic communities in a poorly investigate area of the southern Mediterranean Sea (Gulf of Gabès). Sampling was carried out on the intertidal zone of the Kneiss Islands, firstly in September at the end of the prohibited period and at the beginning of December two months after the beginning of the clam harvesting season, using a Before/After/Control/Impact (BACI) design. This method enables the exploration of a wide range of responses, such as changes in abundance, diversity, richness and biomass of the target species [16]. In this context, BACI is known to be a robust design to detect human impacts [17].

\section{Materials and Methods}

\section{Study site}

The intertidal zone of the Kneiss Islands is located between latitudes $34^{\circ} 10^{\prime}-34^{\circ} 30^{\prime} \mathrm{N}$ and longitudes $10^{\circ} 00^{\prime}-10^{\circ} 30^{\prime} \mathrm{E}$ (Figure 1). Due to the important diversity of benthic communities, the foreshore of the Kneiss Islands represent the largest area in terms of water bird conservation in the Mediterranean zone (Important Bird Areas in 2003) $[15,18]$. The intertidal zone of the Kneiss Islands is composed of muddy to sandy muddy sediments [14,19]. The tidal flats of the Islands contain an important stock of Ruditapes decussatus which is exploited by the local human population $[19,20]$.

\section{Sampling design}

For analysis of the benthic macrofauna, sampling was performed in four replicates with a hand corer $0.15 \mathrm{~m}$ in diameter, corresponding to a sampled surface of $0.018 \mathrm{~m}^{2}$ per replicate and a total surface-area of $0.072 \mathrm{~m}^{2}$ per station; the depth of sampling is $0.3 \mathrm{~m}$. The sampling (Table 1) was carried out at eight independent stations in areas where fishers collect clams Ruditapes spp. and a control station (C) where clam harvesting is normally forbidden (Figure 1). The nine stations located with a GPS were sampled at the end of the prohibited period on 28 September 2013 (denoted B) and during the clam harvesting season on 2 December 2013 (denoted A).

Sediments were sieved through a sieve of $1 \mathrm{~mm}$ mesh size, fixed with buffered formaldehyde $10 \%$ and stained with Rose Bengal to facilitate the sorting. In the laboratory, prior to identification, samples were washed and the organisms were hand sorted into major taxonomic groups, identified to the lowest practical taxonomic level (usually species level) and then counted. Species identification and counting of individuals were performed under a binocular magnifying glass using suitable guides and illustrated keys to identify the benthic species. The animals collected and identified were preserved in $70 \%$ alcohol.

\section{Sediment parameters}

To examine changes in sediment particles size composition at each station before and after clam harvesting, one supplementary sample was collected at the nine stations. Sediment was collected with a shovel removing the surface to a depth of $0.3 \mathrm{~m}$. In laboratory, the sample was desalted with freshwater by successive washing for remove any trace of salt causing crystallization in the grain aggregates. When the sediment contained a significant proportion of very fine particles $(<63 \mu \mathrm{m})$, these latter were firstly separated from the rest of the sample. Then, the sample was dried in an oven at $60^{\circ} \mathrm{C}$ for $24 \mathrm{~h}$ or $48 \mathrm{~h}$ and passed
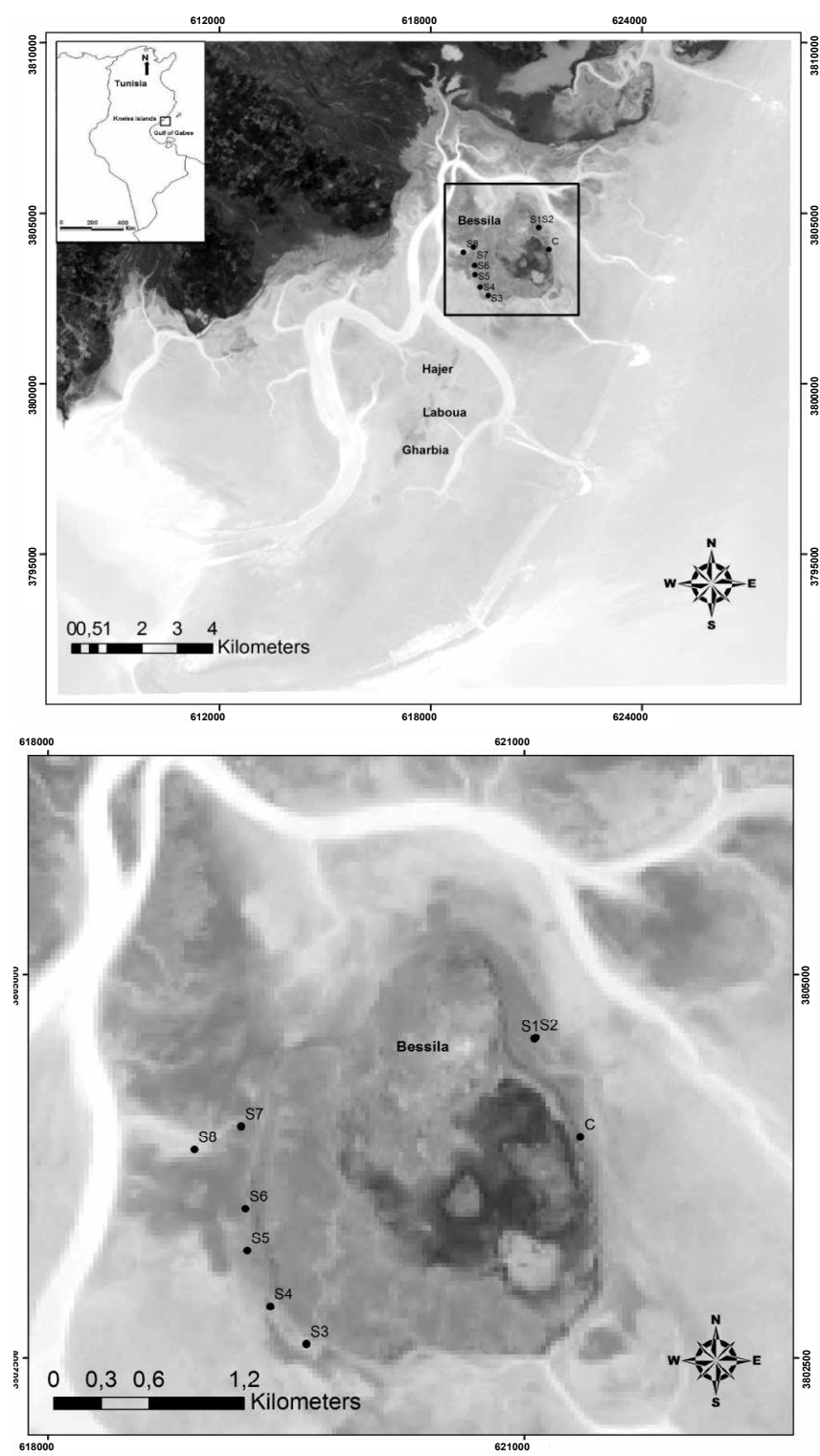

Figure 1: Location of sampling stations around the Kneiss Islands in southeastern Tunisia. 
Citation: Mosbahi N, Pezy JP, Dauvin JC, Neifar L (2016) Immediate Effect of Clam Harvesting on Intertidal Benthic Communities in the Mudflat Zones of Kneiss Islands (Central Mediterranean Sea). J Aquac Res Development 7: 454. doi: 10.4172/2155-9546.1000454

Page 3 of 7

\begin{tabular}{|c|c|c|c|c|c|c|c|c|c|c|c|c|c|c|c|c|c|c|}
\hline Group & CB & CA & S1B & S1A & S2B & S2A & S3B & S3A & S4B & S4A & S5B & S5A & S6B & S6A & S7B & S7A & S8B & S8A \\
\hline Polychaetes (\%) & 30 & 36 & 31 & 43 & 27 & 42 & 31 & 42 & 43 & 43 & 38 & 35 & 48 & 32 & 38 & 40 & 45 & 48 \\
\hline Crustaceans (\%) & 38 & 25 & 19 & 27 & 24 & 33 & 21 & 33 & 20 & 30 & 33 & 44 & 19 & 38 & 36 & 34 & 11 & 22 \\
\hline Mollusc (\%) & 30 & 37 & 50 & 30 & 47 & 25 & 47 & 25 & 35 & 25 & 28 & 21 & 30 & 30 & 26 & 26 & 42 & 30 \\
\hline Others (\%) & 2 & 2 & 0 & 0 & 2 & 0 & 1 & 0 & 2 & 2 & 1 & 0 & 3 & 0 & 0 & 0 & 2 & 0 \\
\hline Taxonomic richness & 41 & 37 & 35 & 19 & 35 & 24 & 38 & 24 & 37 & 21 & 33 & 19 & 34 & 16 & 37 & 15 & 36 & 17 \\
\hline Total abunbance & 6,833 & 5,722 & 4,792 & 1,889 & 4,653 & 2,486 & 5,722 & 2,111 & 5,847 & 1,958 & 4,750 & 2,181 & 4,806 & 1,847 & 5,111 & 1,681 & 4,750 & 1,778 \\
\hline decussatus abundance & 114 & 100 & 86 & 43 & 100 & 0 & 100 & 0 & 86 & 29 & 71 & 57 & 71 & 29 & 114 & 0 & 86 & 14 \\
\hline
\end{tabular}

Table 1: Proportion (\%) of zoological groups sampled at the nine stations in September (B: Before) and December (A: After); Taxonomic richness (number of taxa per 0.072 $\mathrm{m}^{2}$ ); Total Abundance (number of individuals par $\mathrm{m}^{2}$ ) and abundance of Ruditapes decussatus per $\mathrm{m}^{2}$ collected at each station. CB and CA: Control stations; $\mathrm{S} 1, \mathrm{~S} 2, \mathrm{~S} 3$, S4, S5, S6, S7 and S8, stations impacted by clam harvesting.

through a column of 32 sieves with mesh sizes based on the Wentworth and Chester classification [21], using a vibrating sieve (60 amplitudes per min) during $15 \mathrm{~min}$.

\section{Statistical analyses}

The data allowed us to calculate, at each station, the abundance (ind. $\mathrm{m}^{-2}$ ) and the most common biodiversity indices, i.e. taxonomic richness (number of taxa), Shannon index $\left(\mathrm{H}^{\prime}\right)\left(\right.$ bits.ind $\left.^{-1}\right)[22]$ and Pielou's evenness (J) [23]. Analyses of data are performed using PRIMER version 6 (Plymouth Routines in Multivariate Ecological Research) package [24].

For the biological parameters, a Shapiro-Wilk normality test and a Bartlett's test for homogeneity of variance are performed prior to each ANOVA to check whether the assumptions of ANOVA are met and if data transformation is necessary. Then, ANOVAs are performed to assess the effect of clam harvesting on benthic abundance and taxonomic richness for both campaigns (Before/After clam harvesting). Tukey Honestly Significant Difference test was used to determine differences between before and after clam harvesting. The same analyses were performed on the density of Ruditapes decussatus and Ruditapes spp. before and after clam harvesting.

Wilcoxon-Mann-Whitney test was used to compare the number of taxa and the abundance of mollusc and polychaetes at all stations before and after clam harvesting. Wilcoxon-Mann-Whitney test were performed using the software SPSS 20.0.

A dendrogram was created, with group average expressed in the cluster mode using the Bray-Curtis similarity after a square root transformation with the objective of examining intertidal infauna structure. Then, a non-metric multidimensional scaling (n-MDS) ordination, using the Bray-Curtis similarity measure, was applied on the square root abundance of the taxa.

\section{Results}

\section{Sediment composition}

The analyses show that the sediment at the nine stations is mainly composed of fine sand with a median grain size of 125 to $220 \mu \mathrm{m}$. All the stations were colonized by the phanerogam Zostera (Zosterella) noltei Hornemann.

\section{Main faunal characteristics}

Three main zoological groups dominate the macrofauna: i) molluscs, mainly bivalves and gastropods, ii) crustaceans, mainly decapods, amphipods and isopods, and iii) polychaetes. Other groups, such as cnidarians and echinoderms, represent less than $3 \%$ of the recorded individuals (Table 1). Polychaetes make up between 27 and
$48 \%$ of the sampled individuals, crustaceans between 11 and $44 \%$, and molluscs between $21 \%$ and $50 \%$.

Before the clam harvesting period, the fauna composition was mainly dominated by molluscs, the most abundant families being the bivalves Veneridae, Scrobiculariidae and the gastropods Cerithiidae, and also by polychaetes, the most abundant families being Nephtyidae, Cirratulidae, Sabellidae, Maldanidae, Eunicidae and Spionidae. Numerous species of amphipods were found, including Gammarus insensibilis by Stock Leucothoe incisa by Robertson), Microdeutopus gryllotalpa (Costa) and Dexamine spiniventris by Costa.

After clam harvesting, the faunal assemblage appeared similar to that found before clam harvesting, but there was decrease in the number of taxa and abundance per $0.07 \mathrm{~m}^{2}$ (Table 2).

\begin{tabular}{|c|c|c|c|}
\hline $\begin{array}{l}\text { Before clam } \\
\text { harvesting }\end{array}$ & Abundance $/ m^{2}$ & $\begin{array}{l}\text { After clam } \\
\text { harvesting }\end{array}$ & Abundance $/ \mathrm{m}^{2}$ \\
\hline $\begin{array}{l}\text { Cirratulus cirratus } \\
\text { (O.F. Müller, 1776) } \\
\text { Cirratulidae }\end{array}$ & 442 & $\begin{array}{l}\text { Potamides conicus } \\
\text { (Blainville, 1829) } \\
\text { Potamididae }\end{array}$ & 125 \\
\hline $\begin{array}{l}\text { Scrobicularia plana } \\
\text { (Linnaeus, 1758) } \\
\text { Scrobiculariidae }\end{array}$ & 375 & $\begin{array}{l}\text { Scrobicularia plana } \\
\text { Scrobiculariidae }\end{array}$ & 118 \\
\hline $\begin{array}{l}\text { Ruditapes } \\
\text { decussatus } \\
\text { (Linnaeus, 1758) } \\
\text { Veneridae }\end{array}$ & 340 & $\begin{array}{l}\text { Gammarus insensibilis } \\
\text { Stock, } 1966 \\
\text { Gammaridea }\end{array}$ & 111 \\
\hline $\begin{array}{l}\text { Cerithium scabridum } \\
\text { Philippi, } 1848 \\
\text { Cerithiidae }\end{array}$ & 208 & $\begin{array}{l}\text { Euclymene oerstedii } \\
\text { (Claparède, 1863) } \\
\text { Maldanidae }\end{array}$ & 104 \\
\hline $\begin{array}{l}\text { Tricolia speciosa } \\
\text { (Megerle von } \\
\text { Mühlfeld, 1824) } \\
\text { Phasianellidae }\end{array}$ & 167 & $\begin{array}{l}\text { Ruditapes decussatus } \\
\text { (Linnaeus, 1758) } \\
\text { Veneridae }\end{array}$ & 99 \\
\hline $\begin{array}{l}\text { Amphitritides gracilis } \\
\text { (Grube, 1860) } \\
\text { Terebellidae }\end{array}$ & 153 & $\begin{array}{l}\text { Cirratulus cirratus } \\
\text { (O.F. Müller, 1776) } \\
\text { Cirratulidae }\end{array}$ & 97 \\
\hline $\begin{array}{l}\text { Euclymene oerstedii } \\
\text { (Claparède, 1863) } \\
\text { Maldanidae }\end{array}$ & 139 & Maldanidae & 90 \\
\hline $\begin{array}{l}\text { Marphysa bellii } \\
\text { (Audouin \& Milne } \\
\text { Edwards, 1833) } \\
\text { Eunicidae }\end{array}$ & 125 & $\begin{array}{l}\text { Sabella pavonina } \\
\text { Savigny, } 1822 \\
\text { Sabellidae }\end{array}$ & 76 \\
\hline $\begin{array}{l}\text { Ophiura sp } \\
\text { Ophiuridae }\end{array}$ & 118 & $\begin{array}{l}\text { Perinereis cultifera } \\
\text { (Grube, 1840) } \\
\text { Nereididae }\end{array}$ & 69 \\
\hline $\begin{array}{l}\text { Perinereis cultifera } \\
\text { (Grube, 1840) } \\
\text { Nereididae }\end{array}$ & 118 & $\begin{array}{l}\text { Marphysa bellii } \\
\text { (Audouin \& Milne } \\
\text { Edwards, 1833) } \\
\text { Eunicidae }\end{array}$ & 62 \\
\hline
\end{tabular}

Table 2: Ten dominant taxa before and after clam harvesting classified in decreasing rank; abundance are given as the number of individuals reported on $1 \mathrm{~m}^{2}$. 
Citation: Mosbahi N, Pezy JP, Dauvin JC, Neifar L (2016) Immediate Effect of Clam Harvesting on Intertidal Benthic Communities in the Mudflat Zones of Kneiss Islands (Central Mediterranean Sea). J Aquac Res Development 7: 454. doi: 10.4172/2155-9546.1000454

Page 4 of 7

\section{Abundance of Ruditapes decussatus/Ruditapes spp.}

Two Ruditapes species were collected in the samples, i.e. $R$. decussatus and R. philippinarum (Adams and Reeve, 1850) (Figure 2 ). The species $R$. decussatus formed $92 \%$ of the specimens collected before clam harvesting and $100 \%$ after clam harvesting. The density of the Ruditapes spp. varied from 71 to 128 individuals per $\mathrm{m}^{2}$ and those of $R$. decussatus 71 to 114 per $\mathrm{m}^{2}$ before clam harvesting. After clam harvesting, only $R$. decussatus were sampled with density of 0 to 100 individuals per $\mathrm{m}^{2}$. There were significant decreases of clams after the fishing period for Ruditapes spp. (ANOVA, $\mathrm{F}_{1,62=} 88.92 ; \mathrm{p}<0.001$ ) and $R$. decussatus (ANOVA, $\mathrm{F}_{1,62=} 78.05 ; \mathrm{p}<0.001$ ).

\section{Immediate impact of clam harvesting on intertidal benthic communities}

Figure 2 shows the number of taxa, abundance, diversity, Shannon index and Pielou evenness for all stations during both sampling periods, i.e. before and after harvesting. Indeed, the faunistic parameters show high variability during both periods, with taxonomic richness ranging from 15 to 41 , abundance from 1,680 to 6,833 ind. $\mathrm{m}^{-2}$, Pielou's evenness from 0.86 to 0.99 and the Shannon index from 3.7 to 4.8 bits. ind $^{-1}$. The number of taxa on the eight stations differed significantly after clam harvesting (ANOVA, $\mathrm{F}_{17.54}=35.73 ; \mathrm{p}<0.001$; Figure 3). i.e. the stations sampled during the harvesting period show significantly lower abundance compared to the period before harvesting (from 5054 \pm S.D. 471 ind. $\mathrm{m}^{-2}$ before to $1991 \pm$ S.D. 259 ind. $\mathrm{m}^{-2}$ after harvesting). Nevertheless, the control station appeared similar before and after clam harvesting with the 8 stations before clam harvesting. For the taxonomic richness (from $35.7 \pm$ S.D. 1.6 taxa. $0.072 \mathrm{~m}^{2}$ before to 19.4 \pm S.D. 3.4 taxa. $0.07 \mathrm{~m}^{2}$ after harvesting), significant differences are found between both periods (ANOVA, $\mathrm{F}_{17,54}=57.86$; $\mathrm{p}<0.001$; Figure 2). The control station shows higher abundances in both periods, before and during clam harvesting, compared to impacted stations. Likewise, evenness values appear higher after clam harvesting (Figure 3). In summary, clam digging causes a decrease in macrofauna abundance and number of taxa (Figures 2 and 3 ).

Except for the control stations, the abundance of molluscs is significantly reduced after the clam harvesting period $\left(\mathrm{W}=1.10^{6}\right.$; $\mathrm{p}<0.001)$. The data assessment shows a decline in abundance of the clam Ruditapes decussatus (from $87.4 \pm$ S.D. 18.07 ind. $\mathrm{m}^{-2}$ before harvesting to $23.0 \pm$ S.D. 19.5 ind. $\mathrm{m}^{-2}$ after harvesting) between the two sampling period $(\mathrm{W}=35.5 ; \mathrm{p}<0.001)$. Similarly, the polychaetes (mainly composed of the families Spionidae, Maldanidae, Sabellidae and Cirratulidae) show a significant decrease in their taxa number $(\mathrm{W}=39.0, \mathrm{p}<0.01)$ and abundance $\left(\mathrm{W}=18.10^{3}, \mathrm{p}<0.001\right)$ during clam digging.

The dendrogram and MDS ordination (Figure 4) shows the separation of the eighteen samples in three groups: the first group corresponding to the nine stations sampled before the clam harvesting plus the control station two months after the beginning of the clam harvesting period, the two other groups correspond to the After clam harvesting, with respectively one group with six stations (S1A, S3A, S4A, S5A, S7A and S8A), and the last group gathered two stations (S2A and S6A). SIMPER illustrated the biological meaning of the stations clustering before and after harvesting (Figure 4), by displaying the group similarity identifying the species contributing most of the dissimilarity between groups. The group before harvesting was represented by 39 taxa such as Ruditapes decussatus, Cirratulus cirratus, Euclymene oerstedi, and Sabella pavonina. The two second group of stations (S1A, S3A, S4A, S5A, S7A and S8A) was dominated by 20 taxa such as Potamides conicus, Leucothoe incisa, Gammarus insensibilis, and Ruditapes decussatus while the last group of stations (S2A and S6A) was represented by only eight taxa, among them, Corophium insidiosum, Gammarus insensibilis, and Microdeutopus gryllotalpa.

\section{Discussion}

The annual production of clams for Tunisia is approximately 1,100 tonnes in 2013 (DGPA, 2013), and the intertidal zone of the Kneiss Islands represents a high exploited area for Tunisian clam fisheries [13]. The harvesting is mainly ensured by the local population (Picture 1), and represents an important financial resource for these fishers. Consequently, this traditional activity causes major impacts on the intertidal macrobenthos of these sand and mud tidal flats. Hence, this high anthropic pressure on the target species Ruditapes decussatus provides an opportunity to evaluate the effects of clam harvesting on the macrofauna communities of the intertidal zone of the Kneiss Islands.

Clam harvesting has no effects on the fauna composition, which remains similar before and after harvesting; the fauna is mainly dominated by molluscs (Veneridae, Scrobiculariidae and Cerithiidae) and polychaetes (Nereidae, Cirratulidae, Maldanidae, Eunicidae and Spionidae). Moreover, statistically significant changes of the fauna are observed between both periods (before and during harvesting), with a sharp decrease in taxa number and abundance. The depletion of the abundance of the many dominant species, like Ruditapes spp induce an increase of total evenness observed after clam harvesting [25].

Several authors have described similar negative effects due to harvesting on target or non-target species. For example, in a multidisciplinary study of the immediate effects of mechanical clam
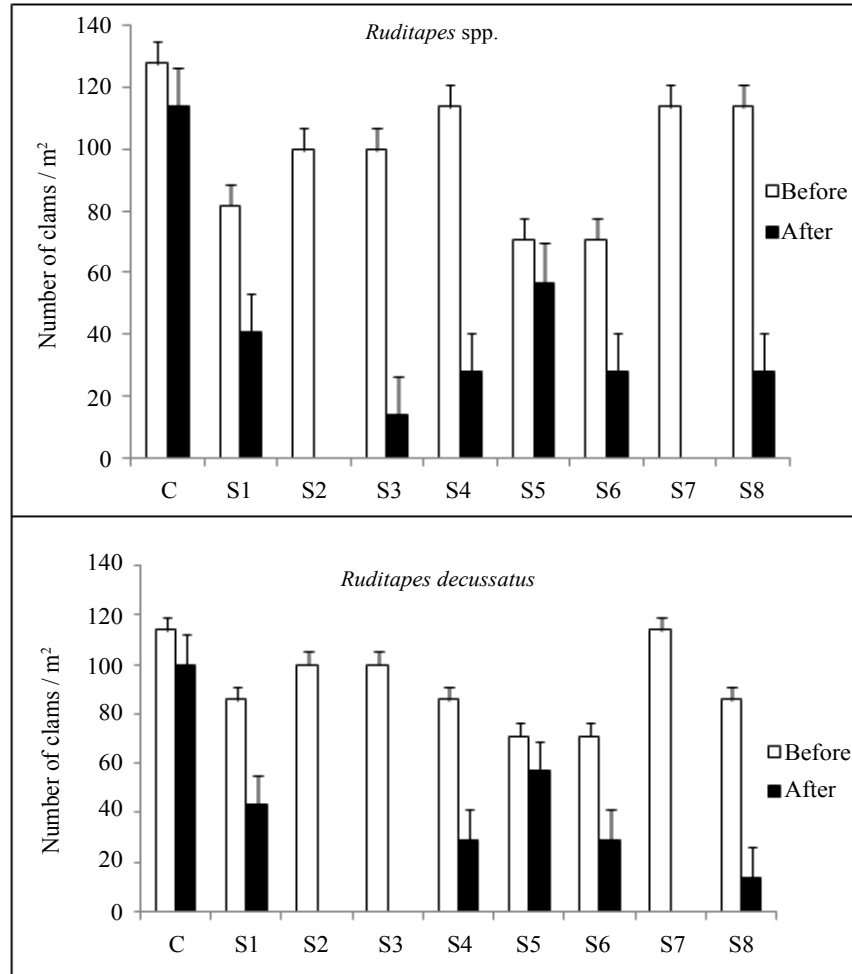

Figure 2: Mean abundance ( $\pm \mathrm{SD}$ ) of Ruditapes spp. and those of $R$ decussatus in the nine sampling stations during before $(B)$ and After $(A)$ clam harvesting periods. 

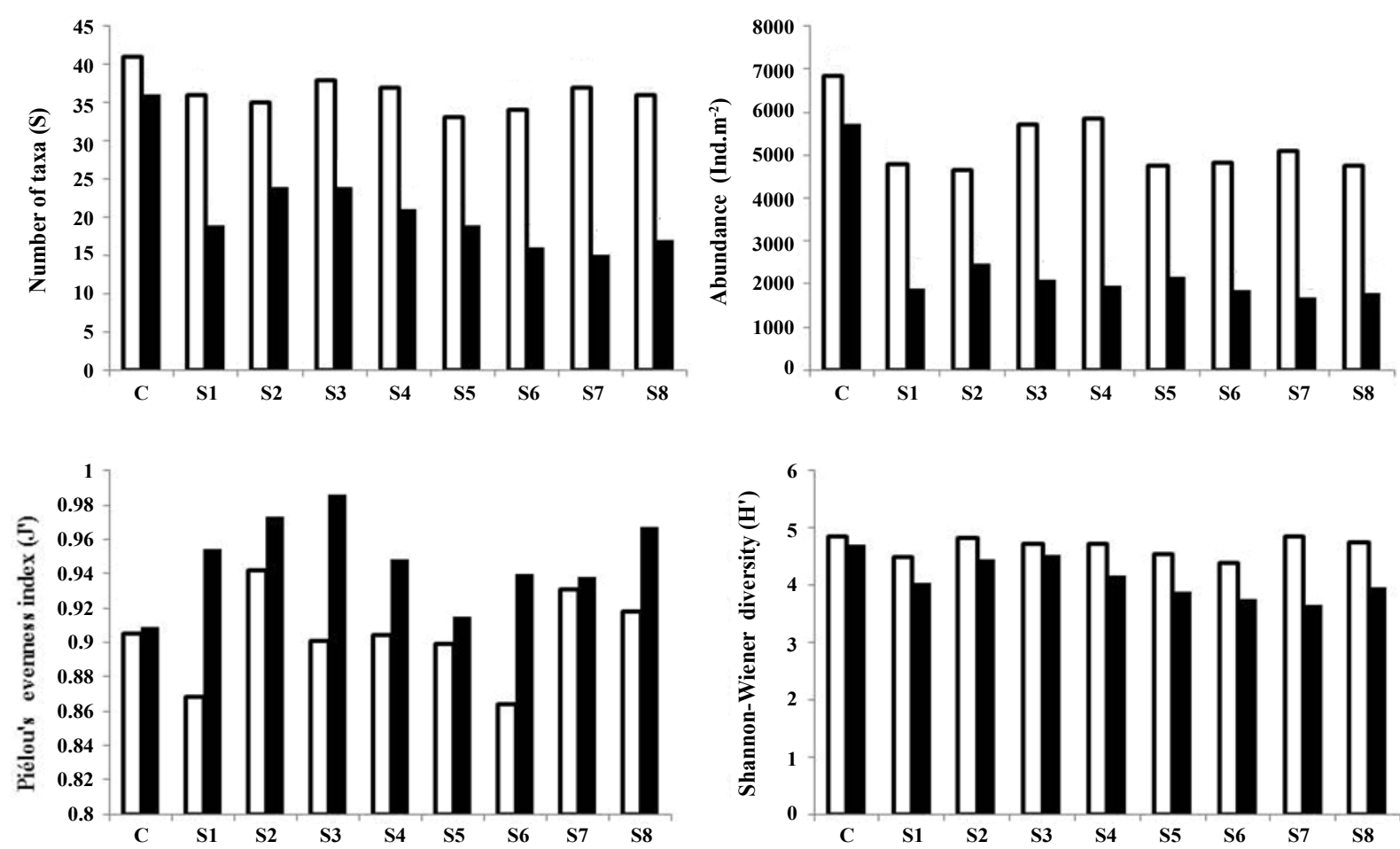

Figure 3: Benthic community parameters: species richness (S), abundance (ind. $\left.\mathrm{m}^{-2}\right)$, Pielou's evenness (J') and Shannon-Wiener index ( $\mathrm{H}^{\prime}$ ) for all stations. White bars represent sampling before clam harvesting and black bars after clam harvesting.

harvesting in the subtidal zone of the Venice lagoon (Italy), Pranovi et al. [26] detected a significant decrease in the total number of individuals after clam fishing. Recently, Navon and Dauvin [9] demonstrated the immediate decrease of coarse sand and gravel benthic macrofauna caused by fork harvesting of the warty Venus clam (Venus verrucosa) on the western coast of Cotentin (Western English Channel).

Nevertheless, in the same area on the intertidal zone at Blainvillesur-Mer (western coast of Cotentin, France), Beck et al. [11] examined the short-term impact of rake harvesting of Ruditapes decussatus and R. philippinarum (Adams and Reeve on the sediment structures, the Ruditapes spp. population and the surrounding macrobenthic species. They report no significant sediment or macrofauna changes after rake harvesting for two of the 'sand and mixed gravelly rocky' fishing habitats. However, the number of clams decreased significantly after raking on the gravelly habitat. This difference was due to sediment transport in the high-energy hydrodynamic environments, which were able to transfer clams and other macrofauna species across the fishing sites, thus minimizing the effects of rake harvesting.

Sometimes, biodiversity loss may persist over long periods, probably due to the reduction of habitat complexity, resulting from the removal of tubicolous organisms and epibenthic species $[27,28]$. These organisms are particularly important as they provide protection for commercial species, and their removal will potentially affect fisheries [28]. Clam harvesting in the Gulf of Gabès has a short-term negative effect on the benthic macrofauna. Indeed, many inexperienced fishers use sickles for collection of clam (sometimes smaller than the commercial size, which is $35.0 \mathrm{~mm}$ ) during low tide [13]. This fishing activity prevents the establishment of benthic communities and thus reduces the stability of the sediment surface, in the same way as observed in the Venice lagoon by Aspden et al. [29]. In addition, human trampling represents another practice with a negative effect on macrofauna biodiversity and the population dynamics of bivalves [7,30]. In this way, Rossi et al. [7] showed that human trampling on the intertidal mudflats of Paulina Polder (Netherlands) could have a negative impact at small scales, clearly modifying the abundance and population dynamics on both the target clams, the Baltic tellin Macoma balthica (Linnaeus) and the cockle Cerastoderma edule. This negative effect on adults of both species is probably due to trampling which directly kills or buries the animals, provoking asphyxia by smothering. In a similar study carried out on the Bay of Cádiz in the south-western Iberian Peninsula, Martinez et al. [31] demonstrated that human trampling was an important disturbing factor for the macrobenthos that inhabit sandy beaches, leading to the decrease of benthic densities and changes in the community structure. Moreover, these authors show that the amphipod Bathyporeia pelagica (Bate) is highly sensitive to human trampling.

The depletion of abundance and diversity of intertidal and subtidal benthic macrofauna after harvesting has been commonly observed, being due to direct and indirect mortality (e.g. destruction of tubes, exposure to predators, and loss of individuals from the unstable sediments via water currents) $[1,32,33]$. Indeed, the abundance of sedentary polychaetes belonging to tubicolous families, i.e. Spionidae, Sabellidae, Serpulidae, Maldanidae and Cirratulidae, especially Cirratulus cirratus (O.F. Müller) generally decreases after the impact $[33,34]$. The vulnerability of sedentary organisms such as deposit feeders to fishing disturbance has been already documented by De Juan et al. [34], while Spionidae were also found to be affected by bivalve dredging in southern Portugal [33]. This indicates that the lifehistory traits of different infauna species affect their ability to survive during a periodic disturbance, suggesting that frequent fishing could select specific life-history strategies and possibly functional groups as well. Therefore, clam harvesting is likely to have a significant effect on the functioning of ecosystems and turnover within the system $[29,35]$. 
Citation: Mosbahi N, Pezy JP, Dauvin JC, Neifar L (2016) Immediate Effect of Clam Harvesting on Intertidal Benthic Communities in the Mudflat Zones of Kneiss Islands (Central Mediterranean Sea). J Aquac Res Development 7: 454. doi: 10.4172/2155-9546.1000454

Page 6 of 7

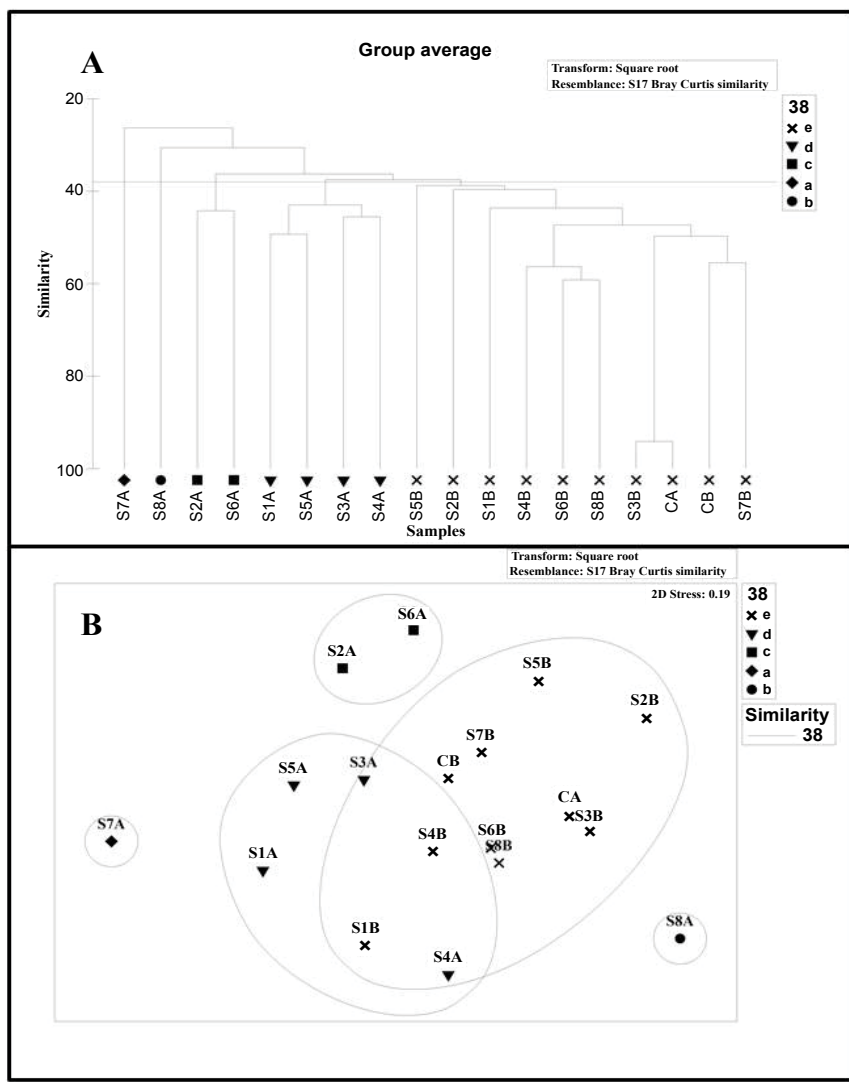

Figure 4: Dendrogram (A) and n-MDS ordination (B) of bray-Curtis similarities from abundance data (square root transformation) before and after clam harvesting on 8 stations and one control station. (B: before; A : after; $1,2,3,4,5,6,7,8$ : clam harvesting stations; $\mathrm{C}$ : control station).

In the intertidal zone, the mechanical harvesting of commercial bivalves at high tide creates strong disturbances and has a negative effect on the associated benthic fauna communities $[1,5,11]$.

\section{Conclusion}

In conclusion, this study on the Gulf of Gabès intertidal zone shows that Ruditapes decussatus harvesting leads to a decrease of the target species population, as well as a reduction of the taxonomic richness and abundance of the surrounding macrofauna. It is well known that the macrofauna plays a crucial role in the food web, either by feeding on detritus, or as food for aquatic birds and economically important demersal [36,37]. Therefore, high anthropogenic harvesting pressure could have consequences on the availability of benthic preys, leading predators having to find nourishment elsewhere. Intensive clam harvesting and human trampling (more than 400 fishers per day on a limited area over the eight months of the authorized harvesting period [37]).

Thus, for the next few years, it will be very important to improve control of this activity by limiting the number of fishers and forbidding digging in fragile zones such as Zostera noltei meadows. Furthermore, this first study should be followed by a long-term monitoring assessment to assess the effect of such high pressures on the intertidal zone of the Kneiss Islands, which is a protected area [18]. Moreover in a view of conservation practice, it will be advantageous to identify the direct and indirect threats affecting the clam population decline due to an overexploitation and the physical disturbance due to fishing [38].

\section{Acknowledgements}

The authors thank Alexandrine Baffreau for her help in species identification, Michael Carpenter for the English revision and the fishers of the Kneiss Islands for their help during the sampling. The authors thank also the two reviewers of the first version of the typescript for their useful suggestions.

\section{References}

1. Brown B, Wilson WH (1997) The role of commercial digging of mudflats as an agent for change of infaunal intertidal populations. Journal of Experimental Marine Biology and Ecology 218: 49-61

2. Kaiser MJ, Broad G, Hall SJ (2001) Disturbance of intertidal soft-sediment benthic communities by cockle hand raking. Journal of Sea Research 45: 119130

3. Thrush S, Dayton P (2002) Disturbance to marine benthic habitats by trawling and dredging: Implications for marine biodiversity. Annual Review of Ecology and Systematics 33: 449-473.

4. Griffiths J, Dethier MN, Newsom A, Byers JE, Meyer JJ, et al. (2006) Invertebrate community responses to creational clam digging. Marine Biology 149: 1489-1497.

5. Spencer BE, Kaiser MJ, Edwards DB (1998) Intertidal clam harvesting: benthic community change and recovery. Aquaculture Research 29: 2077-2090.

6. Carbines G, Jiang W, Beentjes MP (2004) The impact of oyster dredging on the growth of blue cod, Parapercis colias, in Foveaux Strait, New Zealand. Aquatic Conservation: Marine and Freshwater Ecosystems 14: 491-504.

7. Rossi F, Forster RM, Montserrat F, Ponti M, Terlizzi A, et al. (2007) Human trampling as short-term disturbance on intertidal mudflats: effects on macrofauna biodiversity and population dynamics of bivalves. Marine Biology 151: 2077-2090.

8. Carvalho S, Constantino R, Pereira F, Ben-Hamadou R, Gaspar MB (2011) Relationship between razor clam fishing intensity and potential changes in associated benthic communities. Journal of Shellfish Research 30: 309-323.

9. Navon M, Dauvin JC (2013) The immediate impact of intertidal pebble fork harvesting on the warty venus Venus verrucosa benthic community. Cahiers de Biologie Marine 54: 385-392.

10. Sousa LFM, Gaspar MB (2007) Immediate effect of intertidal non-mechanised cockle harvesting on macrobenthic communities: a comparative study. Scientia Marina 71: 723-733.

11. Beck F, Pezy JP, Baffreau A, Dauvin JC (2015) Effects of clam rake harvesting on the intertidal Ruditapes habitat of the English Channel. ICES Journal of Marine Science 72: 2663-2673.

12. Sammari C, Koutitonsky VG, Moussa M (2006) Sea level variability and tida resonance in the Gulf of Gabès, Tunisia. Continental Shelf Research 26: 338350 .

13. Nouaili R (2013) Etude sur la faisabilité de certification MSC de la pêcherie des palourdes en Tunisie, Master International en gestion pesquera sostenible (4thedn), Université d'Alicante, Espagne.

14. Bali M, Gueddari M (2011) Les chenaux de marée autour des îles de Kneiss, Tunisie: sédimentologie et évolution. Hydrological Sciences Journal 56: 498506.

15. Mosbahi N, Boudaya L, Dauvin JC, Neifar L (2015) Spatial distribution and abundance of the intertidal benthic macrofauna from the Kneiss islands (Gulf of Gabès, Tunisia). Cahiers de Biologie Marine 56: 319-328.

16. Torres A, Palacín C, Seoane J, Alonso JC (2011) Assessing the effects of a highway on a threatened species using before-during-after and before-duringafter-control-impact designs. Biological Conservation 144: 2223-2232.

17. Aguado-Giménez F, Piedecausa MA, Gutiérrez JM, García-Charton JA Belmonte A (2012) Benthic recovery after fish farming cessation: a "beyond BACl" approach. Marine Pollution Bulletin 64: 729-738.

18. MAEW (2005) Gulf of Gabès: Marine and coastal resources protection project No 27479, Tunis, Tunisia.

19. Abdennadher A, Ramirez F, Romdhane MS, Ruiz LJ, Sanpera C (2010) Biomonitoring of coastal areas in Tunisia: Stable isotope and trace element analysis in the Yellow-legged Gull. Marine Pollution Bulletin 60: 440-447.

20. Mosbahi N, Pezy JP, Dauvin JC, Neifar L (2016) Spatial and temporal structures 
Citation: Mosbahi N, Pezy JP, Dauvin JC, Neifar L (2016) Immediate Effect of Clam Harvesting on Intertidal Benthic Communities in the Mudflat Zones of Kneiss Islands (Central Mediterranean Sea). J Aquac Res Development 7: 454. doi: 10.4172/2155-9546.1000454

of the Macrozoobenthos from the intertidal zone of the Kneiss Islands (Central Mediterranean Sea). Open Journal of Marine Science 6: 223-237.

21. Wentworth CK, Chester K (1922) A scale of grade and class terms for clastic sediments. The Journal of Geology 30: 377-392.

22. Shannon CE, Weaver W (1963) The Mathematical theory of communication. University Illinois Press, Urbana.

23. Pielou EC (1966) Shannon's formula as a measure of specific diversity: its use and measure. American Naturalist 100: 463-465

24. Clarke KR, Gorley RN (2006) Primer v6: User Manual/Tutorial Primer-E Ltd, Plymouth.

25. Battisti C, Poeta G, Fanelli G (2016) An introduction to disturbance ecology: A road map for wildlife management and conservation. Springer, The Netherlands.

26. Pranovi F, Da Ponte F, Raicevich S, Giovanardi O (2004) A multidisciplinary study of the immediate effects of mechanical clam harvesting in the Venice Lagoon. ICES Journal of Marine Science 61: 43-52.

27. Dayton PK, Thrush SF, Agardy T, Hofman RJ (1995) Viewpoint: Environmental effects of marine fishing. Aquatic Conservation: Marine and Freshwater Ecosystems 5: 205-232.

28. Kaiser MJ, Ramsay K, Richardson CA, Spence FE, Brand AR (2000) Chronic fishing disturbance has changed shelf sea benthic community structure. Journal of Animal Ecology 69: 494-503.

29. Aspden RJ, Vardy S, Perkins RG, Davidson IR, Bates R, et al. (2004) The effects of clam fishing on the properties of surface sediments in the lagoon of Venice, Italy. Hydrology Earth System Sciences 8: 160-169.

30. Reyes-Martinez MJ, Ruiz-Delgado MC, Sanchez-Moyano JES, Garcia FJG
(2015) Response of intertidal sandy-beach macrofauna to human trampling: An urban vs Natural beach system approach. Marine Environmental Research 103: 36-45.

31. Cowie PR, Widdicombe S, Austen MC (2000) Effects of physical disturbance on an estuarine intertidal community: field and mesocosm results compared. Marine Biology 136: 485-495.

32. Munari C, Balasso E, Rossi R, Mistri M (2006) A comparison of the effects of different types of clam rakes on non-target, subtidal benthic fauna. Italian Journal of Zoology 73: 75-82.

33. Carvalho S, Constantino R, Cerqueira M, Pereira F, Subida MD, et al. (2013) Short-term impact of bait digging on intertidal macrozoobenthic assemblages of two Iberian Atlantic systems. Estuarine, Coastal and Shelf Science 132: 65-76.

34. De Juan S, Thrush SF, Demestre M (2007) Functional changes as indicators of trawling disturbance on a benthic community located in a fishing ground (NW Mediterranean Sea). Marine Ecology Progress Series 334: 117-129.

35. Emmerson MC, Solan M, Emes C, Paterson DM, Raffaelli D (2001) Consistent patterns and the idiosyncratic effects of biodiversity in marine ecosystems. Nature 411: 73-77.

36. Le Mao P, Pasco PY, Provost S (2006) Consommation de la macrofaune invertébrée benthique par les oiseaux d'eau en baie du Mont-Saint-Michel. Alauda 74: 23-36.

37. Direction Générale de la Pêche et de l'Aquaculture (2013) Statistiques de la Pêche et de l'Aquaculture de la Tunisie.

38. Salafsky N, Margoluis R, Redford KH, Robinson JG (2002) Improving the practice of conservation: a conceptual framework and research agenda for conservation science. Conservation Biology 16: 1469-1479. 